PROBLEMS

OF EDUCATION

IN THE $21^{\text {st }}$ CENTURY

Volume 42, 2012

50

\section{IMPROVING THE QUALITY OF LEARNING BY INCREASING THE STUDENTS' READING SKILLS}

\author{
Aljula Jubani, Irena Ndoci Lama, Mimoza Gjokutaj \\ University of Tirana, Tirana, Albania \\ E-mail: jubanialjula@yahoo.it, irenalama@yahoo.it, mgjokutaj@yahoo.com
}

\begin{abstract}
Recently, the quality of students learning in many European schools has decreased. Various studies and evaluations of the Albanian education system have revealed that Albanian schools have low quality indicators. The reasons for this phenomenon are related to different educational and social factors.

One of the factors that has significantly contributed to the low results of the Albanian students is the low quality of reading, which in turn has a direct impact on learning outcomes.

This study aims at reflecting the state of reading and its related issues as well as the use of current techniques and strategies which aim to enhance critical thinking through reading and writing.

In order to highlight some of the factors that can significantly affect the quality of reading for female $/$ male students in rural and urban areas, around 300 students from 18 schools in 6 regions of the country were examined.

Findings and recommendations are presented for the use of new strategies and techniques related to reading and improving the quality of student learning by improving the quality of the reading.
\end{abstract}

Key words: critical thinking, quality of learning, reading, results, skills, strategies, techniques.

\title{
Introduction
}

Learning is the acquisition of knowledge or skill through education and experience. Knowledge and skills enhance people's ability to meet their basic needs, widen the range of options open to them in every sphere of life, and enable them to influence the direction their lives take. Conceives of learning as a relatively permanent change in behaviour with behaviour including both observable activity and internal processes such as thinking, attitudes and emotions (Burns 1995). In an ever changing society learning is essential for everyone as it enables them to survive. In the case of education of education the acquisition of knowledge and skills is closely related to reading. Reading skills are important all life so students must appreciate the fact that reading is a skill they should endeavor to master for the rest of their lives. Research findings in applied linguistics have shown that students who know how to read and understand what they read have a better school performance compared to his peers. Children who have been exposed to stories while still young do far better than the others and are better at reading and writing (Heath 1983; Elley 1991; Fashela 1995). The final goal of reading is ccomprehension, which is not simply a matter of recognizing or understanding individual words. Comprehension means to understand what the text means. This is achieved by using some self-regulated comprehension strategies, such as prior knowledge activation, question generation, creating mental images during reading, summing up. Reading comprehension is a process that requires integration across a range of sources of information, from lexical 
features through to knowledge concerning events in the world (Garnham, 2001; Gernsbacher, 1990; Kintsch, 1998). Students who read, write, discuss and confront various types of materials related to learning in the most varied ways, are likely to learn more as they relate what they know with the new material. Comprehension means understanding the message that the print conveys (Nation, 2005: 41).

Work in the field of improving the quality of teaching and learning in undergraduate education has been continuous. School, as the institution through which knowledge and skills are taught, sees reading as the key to success of every individual in all ages of his education, which opens doors to student learning. The importance of being able to read to learn is particularly imperative when seen in the light of the role that textbooks and other books play in the learning context points out the importance of reading for people (Grabe, 1991: 389).

Reading is a process that helps people to acquire knowledge, to meet their cognitive and emotional needs. Reading for comprehension does not simply mean decoding letters and words. It involves skills, techniques and patterns. Reading ability is related to a wide range such as personal ability and skills, competences and, social practices, goals and values.

Considering developing the ability to read as a priority to teaching, reading is seen as a process and as a communication skill. Today's problems on reading, learning to read, reading to learn, ability to read and teaching reading have been objects of study for many researchers. For researchers and psychologists reading process is complicated by several issues that create difficulties to be overcome. Reading is a basic life skill. It is a cornerstone for success at school and life. Without the ability to read well, opportunities for self-realization and professional success, no doubt you will lose. It's hard to imagine a different skill to better illustrate the purpose of education.

The results of Pisa showed the low reading levels of students in Albania. Given the strong relationship between reading ability and academic performance, there is a compelling need for research in this issue.

\section{Problem of Research}

The study will address several issues related to the field of reading. It will identify some of the current problems in teaching reading students throughout the pre university system, the quality of reading in some pilot schools involved and assisted for several years by the organization Save the Children, which specialized assistance in support of quality improvement in education has been ongoing.

It gives an insight of the problems and challenges to reading the school faces and some suggestions of how to solve these problems based on the best international and national experience. The study investigates reading strategies students use and how the teachers work to teach the right strategies.

A very important issue is what and how students read, because this is seen related to reading comprehension and to better academic performance. Repeated reading activities of the same stories and exposure to a wide variety of stories enable children to develop story knowledge, which then facilitates comprehension (Mason and Allen, 1986; Van Kleeck, 1990).

\section{Research Focus}

The research was conducted in six regions of the country, Dibër, Durrës, Korça, Elbasan, Vlora, Gjirokastra, in three schools for each district comprising about 300 students aged 11 that are a sample consisting of city and country students, both female and males.

The focus of the study is the reading comprehension ability of the Albanian students aged 11 , fluency and speed of reading. This is seen through reading comprehension tests, surveys and 
PROBLEMS

OF EDUCATION

IN THE $21^{\text {st }}$ CENTURY

Volume 42, 2012

questionnaires. The districts chosen are located in all the territory of Albania so that to draw conclusions at regional level and to make comparisons among schools and students as the basic purpose of the study. These data also serve to have national generalizations of phenomena and important issues related to children's reading at the end of elementary school.

It also highlights errors that students make in reading. The focus of the study was the evaluation of the teacher and his students on the reading of a. The problems encountered reflection students' and teacher' attitude to reading. Teachers sometimes pay more attention to fluent reading aloud rather than reading comprehension.

Through this survey whose data were taken from the teachers there were gathered ideas and general assessments on the belief that students have about the reading. The study analyses the way teachers assess and evaluate reading. The way they conduct this assessment and the results of class observations gives an insight of what really happens in class, the beliefs of teachers and students about reading and about the problems they encounter.

\section{Methodology of Research}

\section{General Background of Research}

In the global context of learning and use of information technologies the question of improving the quality of reading becomes even more important. For this reason, professional events such as conferences, seminars and meetings have become ever more rapid and specific problem. Of course, this problem however diverse in its essence is the issue of understanding of reading and its service is in order to increase the quality of students. Certainly for the positive steps to be undertaken in this process we should rely on a real context for learning about different communities. Testing the quality of reading in the context of learning has been and will remain a process of continuity in this field. There is an increasing number of students with reading difficulties. These groups are divided into disorders of learning and reading problems. The statistics speak for the need to improve the mode of delivery of literacy, the need that all teachers should have the knowledge required for the study of many fundamental issues on the teaching of reading and developing reading skills.

Teachers and school psychologists must have thorough knowledge of reading processes and effective teaching from the moment the process starts up to years of maturity of each individual as a mature reader in this important process for obtaining knowledge. Starting in first grade and consistently, many students experience difficulty in reading.

Rather than the process of reading, our psychologists and researchers are focused to the literature and its problems in the case of reading by pupils and students and not to the causes of this process and finding anomalies that occur in various school age about reading. Although it is understood that the quality of student learning in school depends on the quality of their reading in Albania studies in this area are still scarce. Albanian teachers come from a background where language and grammar teaching in school was primary and reading was underestimated. They continue to think that learning grammar is crucial to gain reading skills.

\section{Sample of Research}

Sample of research are about 300 pupils in fifth grade, to 18 schools from six different regions of the country. 12 schools are urban, while 6 of them are rural. Search is somewhat limited and includes a community of pupils. Teachers of these schools were in a training process in the improvement of the quality of learning supported by Save the Children. From the village are a total of 83 pupils of which 41 girls and 42 boys. Besides the six pupils regions underwent the test to the same school teachers who completed a questionnaire. 
The study relies on four instruments used by pupils and their teachers:

1. A structured test was delivered to a group composed of 17 pupils from 18 schools in six provinces of Albania;

2. A survey was given the same students with questions what students read and their authors who are preferred;

3. An evaluation sheet was given to teachers to students to measure the velocity and pupils' errors in reading;

4. A watch list was given to the same teacher beliefs about students in reading.

Tests are based on standards of fifth grade program approved by the Ministry of Education and science. It was prepared in collaboration with specialists in the field of employee assessment currently in the National Achievement Agency. The test consists of 6 questions and a sheet with the text each student read. The test was designed in such a way as to allow the measurement of students' abilities to comprehend what they read. Through this test, and items that it comprises, it was aimed to see how the students understand what they read, know how to explain new vocabulary terms, know how to connect the logical structure of sentences and groups of words, how to characterize characters that move through texts they read, etc..

Secondly, it was measured the accuracy and speed of reading. It aimed to measure the speed of reading in a minute, the number of words they read in a minute and the time spent to read a standard text for all. This test was performed by chronometrical means of a high precision. This test yields not only results in a comparative way, but based on the relevant standard, it reveals the phenomenon of illiteracy in some groups of students.

Third, this test sets a standard on quality and speed of reading of students at the end of compulsory education to elementary. It may be used by main stream teachers.

Fourth, through a survey with teachers of students tested, their opinion about the quality of reading was seen. Data from the survey reveal problems related to standard of teaching, teachers and students. Survey conducted with the same students got information about what students read, books they have read recently and their favorite authors, what do they know about the texts they read. This information is very interesting, convey a broader issue about what was taught and required students to read. Details of this survey follow another problem which relates to standards of learning, with students and teachers. From the evaluation sheets and a list of the survey that was given to teachers of students tested, got their opinion about the quality of reading to students.

\section{Data Analysis}

Scientific methodology applied aims to provide accurate data on the issue at stake. At the end of this broad approach, through the material collected was processed a variety of information in statistical tables that make reliable conclusions of this study.

The students participating in the study were given a story: "Eye of the Sea" of the Albanian writer for children Liljana Cukalla. It was tested their ability to comprehend the story. It also tested their accuracy and speed of reading. The questions were on knowledge, guessing, finding true - false statement, analyses and evaluation.

The observer kept accurate records in the accompanying leaflet for speed of reading, with symbols marking the students' errors in reading, which were classified in several groups: dialect words, dining and adding letters, repeated reading of words, read a different word and intonation problems. Problems from one area to another were once the same and sometimes different type.

The following table gives the maximum points for a sample of 17 students in each school. 
PROBLEMS

OF EDUCATION

IN THE $21^{\text {st }}$ CENTURY

Volume 42, 2012

Table 1. Maximum points for the 6 questions given to samples of 17 students.

\begin{tabular}{|c|c|}
\hline Questions 1 & 5 points $\times 17$ students $=85$ points \\
\hline Questions 2 & 2 points $\times 17$ students $=34 ;$ \\
Questions 2/1 & 4 points $\times 17$ students $=64$ \\
& 98 points \\
\hline Questions 3 & 3 points $\times 17$ students $=51$ points \\
\hline Questions 4 & 4 points $\times 17$ students $=68$ points \\
\hline Questions 5 & 3 points $\times 17$ students $=51$ points \\
\hline Questions 6 & 3 points $\times 17$ students $=51$ points \\
\hline Total & Each group of students has 408 points \\
\hline
\end{tabular}

In the table above shows the total points that need to take, any group of students for the test provided. The maximum number of points for each student was 24 and for the whole group of 17 pupils was 408 . From tests and surveys of students and the evaluation sheet and a list of teacher survey was designed tables for each school with test scores for each student. The tables present results for six test questions, total points, average grade, the speed of reading words in a minute and story reading time for each student. Through statistical data obtained information about the quality of reading female-female, urban schools, village schools, school project, comparative schools, etc.

\section{Results of Research}

In Durrës the test was given to three schools: "M. Kaçulini", "Kushtrimi i Lirise" and "M. Dollaku". From each school 17 students participated. School "M. Kaçulini $\square$ is a city school participating the project, school "Kushtrimi i Lirise" is a comparative school and school "M. Dollaku" is included in the program of Save the Children in countryside.

The school "M. Kaçulini":

Question $1-89 \%$ of students match parts of sentences according to the meaning;

Question $2-88 \%$ of students find interrogative sentences in the text;

Question 2/1 - 84\% of students find words for action in the text;

Question $3-88 \%$ of students find true or false statement related to the content of the text;

Question $4-50 \%$ of students explain the meaning of vocabulary words;

Question $5-50 \%$ of the students analyze characters;

Question $6-50 \%$ of students say that they have read novels.

The problem here lies in what they read. The answer is random and not associated with the desire and willingness to read. From 408 test points that all the students of this class have received about 296 points. Grade passing rate is $72 \%$ with an average grade 8.5 . In this class was achieved average reading speed of $2.16^{\prime}$ in a text with 265 words.

The school "Kushtrimi i Lirisë":

Question $1-89 \%$ of students match parts of sentences according to the meaning;

Question $2-66 \%$ of students find words for action in the text;

Question 2/1 - 50\% of students find words for action in the text;

Question $3-90 \%$ of students find true or false statement related to the content of the text;

Question $4-70 \%$ of students explain the meaning of vocabulary words; 
Question 5 - 84\% of students analyze characters;

Question $6-80 \%$ of students say that they have read novels.

The problem here lies in what they read. The answer is random and not associated with the desire and willingness to read. From 408 test points that all the students of this class have received about 309 points. Grade passing rate is $79 \%$ with an average grade 8.3. In this class was achieved average reading speed of $2.43^{\prime}$ in a text with 265 words.

The school "M. Dollaku":

Question $1-76 \%$ of students match parts of sentences according to the meaning;

Question $2-50 \%$ of students find words for action in the text;

Question 2/1 - 23\% of students find words for action in the text;

Question 3 - 54\% of students find true or false statement related to the content of the text;

Question $4-44 \%$ of students explain the meaning of vocabulary words;

Question 5 - 84\% of students analyze characters;

Question 6 - 68\% of students say that they have read novels.

The problem here lies in what they read. The answer is random and not associated with the desire and willingness to read. From 408 test points that all the students of this class have received about 228 points. Grade passing rate is $55 \%$ with an average grade 8.3 . In this class was achieved average reading speed of $2.03^{\prime}$ in a text with 265 words.

Table 2. The test scores from three schools in the district of Durrës.

\begin{tabular}{|l|l|c|c|c|c|c|c|c|c|c|c|}
\hline & School & Q1 & Q2 & Q3 & Q4 & Q5 & Q6 & Total & $\begin{array}{c}\text { Average } \\
\text { Grade }\end{array}$ & Words/1m & $\begin{array}{c}\text { Read- } \\
\text { ing } \\
\text { Time }\end{array}$ \\
\hline 1 & M. Kaçulini & 76 & $30 / 38$ & 45 & 34 & 45 & 45 & 296 & 8.5 & 122.3 & 2.16 \\
\hline 2 & $\begin{array}{l}\text { Kushtrimi i } \\
\text { lirisë }\end{array}$ & 76 & $30 / 34$ & 46 & 48 & 43 & 41 & 309 & 8.3 & 107.6 & 2.47 \\
\hline 3 & M. Dollaku & 65 & $15 / 16$ & 28 & 30 & 43 & 35 & 228 & 6.4 & 107.2 & 2.03 \\
\hline 4 & $\begin{array}{l}\text { Durrës } \\
\text { /Total }\end{array}$ & 217 & 163 & 119 & 112 & 111 & 121 & 883 & 7.5 & 112.3 & 2.22 \\
\hline
\end{tabular}

The urban school participating in the project has the best results compared with the two other schools. In the rural areas school "M. Dollaku" there are lower results, but not too poor. School "M. Dollaku" has the best results from other regions in the group of rural schools. A noticeable phenomenon in the group of students of this school are students significant weaknesses in reading. Four of them have difficulty in reading and one is completely illiterate.

In region of Korça the test is given to three schools. The class of the rural school of Zvezda has scored the lowest points in the study.

Table 3. The test scores from three schools in the district of Korça.

\begin{tabular}{|l|l|c|c|c|c|c|c|c|c|c|c|}
\hline & School & Q1 & Q2 & Q3 & Q4 & Q5 & Q6 & Total & $\begin{array}{c}\text { Average } \\
\text { Grade }\end{array}$ & $\begin{array}{c}\text { Words/ } \\
\text { 1m }\end{array}$ & $\begin{array}{c}\text { Reading } \\
\text { Time }\end{array}$ \\
\hline 1. & Korça-Maliq & 73 & $26 / 18$ & 45 & 53 & 44 & 35 & 292 & 7.5 & 128 & 1.45 \\
\hline 2. & $\begin{array}{l}\text { Korça- Demokra- } \\
\text { cia }\end{array}$ & 72 & $27 / 18$ & 38 & 36 & 33 & 24 & 247 & 6.8 & 103.2 & 2.33 \\
\hline 3. & Korça-Zvezda & 77 & $26 / 19$ & 38 & 45 & 34 & 30 & 267 & 7.8 & 126.4 & 1.86 \\
\hline 4. & Korça & 222 & $79 / 55$ & 121 & 134 & 111 & 89 & 806 & 7.3 & 119.2 & 1.88 \\
\hline
\end{tabular}


PROBLEMS

OF EDUCATION

IN THE $21^{\text {st }}$ CENTURY Volume 42,2012

Question $1-82 \%$ of students match parts of sentences according to the meaning;

Question $2-52 \%$ of students find words for action in the text;

Question 2/1 - 45\% of students find words for action in the text;

Question $3-70 \%$ of students find true or false statement related to the content of the text;

Question $4-48 \%$ of students explain the meaning of vocabulary words;

Question 5 - 74\% of students analyze characters;

Question 6-58\% of students say that they have read novels.

The problem here lies in what they read. The answer is random and not associated with the desire and willingness to read. From 408 test points that all the students of this class have received about 240 points. Grade passing rate is $61 \%$ with an average grade 6.7 . In this class was achieved average reading speed of $2.20^{\prime}$ in a text with 265 words. This class has scored the lowest points in the study. They have great difficulty in explaining the meaning of words or guessing their meaning. Almost half of them read with difficulty and 4 are illiterate. There is difference between girls and boys in literacy skills, where girls are better.

In region of Elbasan the test is given to three schools. The class of the rural school of Kuqan has scored the lowest points in the region.

Table 4. The test scores from three schools in the district of Elbasan.

\begin{tabular}{|l|l|c|c|c|c|c|c|c|c|c|c|}
\hline & \multicolumn{1}{|c|}{ School } & Q1 & Q2 & Q3 & Q4 & Q5 & Q6 & Total & $\begin{array}{c}\text { Average } \\
\text { Grade }\end{array}$ & $\begin{array}{c}\text { Words/ } \\
\text { 1m }\end{array}$ & $\begin{array}{c}\text { Reading } \\
\text { Time }\end{array}$ \\
\hline 1 & $\begin{array}{l}\text { Elbasan } \\
\text {-F.Gurmani }\end{array}$ & 69 & $20 / 8$ & 41 & 39 & 34 & 36 & 246 & 7.4 & 126.6 & 2.19 \\
\hline 2 & Elbasan - A. Agjan & 72 & $32 / 22$ & 38 & 59 & 49 & 36 & 314 & 8.2 & 120.6 & 1.73 \\
\hline 3 & Elbasan - Kuqan & 71 & $20 / 12$ & 31 & 29 & 38 & 22 & 222 & 7.0 & 102.1 & 2.89 \\
\hline 4 & Elbasan - Total & 212 & $72 / 42$ & 111 & 127 & 121 & 94 & 782 & 7.53 & 116.4 & 2.27 \\
\hline
\end{tabular}

Question 1 - 83\% of students match parts of sentences according to the meaning;

Question $2-58 \%$ of students find words for action in the text;

Question 2/1 - 17\% of students find words for action in the text;

Question $3-60 \%$ of students find true or false statement related to the content of the text;

Question 4 - 42\% of students explain the meaning of vocabulary words;

Question 5 - 74\% of students analyze characters;

Question 6-43\% of students say that they have read novels.

The problem here lies in what they read. The answer is random and not associated with the desire and willingness to read. From 408 test points that all the students of this class have received about 222 points. Grade passing rate is $56 \%$ with an average grade 7 . In this class was achieved average speed of 2.43 ' reading in a text with 265 words. As a rural school noticed weakness apparent to some students in reading, but not on the verge of complete illiteracy. It should be noted that the students in the schools in the region of Elbasan have a good reading skills shown by the scores of the test given.

In region of Vlora the test is given to three schools. The class of the rural school of Orikum has scored the lowest points in the region. 
Table 5. The test scores from three schools in the district of Vlora.

\begin{tabular}{|l|l|c|c|c|c|c|c|c|c|c|c|}
\hline \multicolumn{1}{|c|}{ School } & Q1 & Q2 & Q3 & Q4 & Q5 & Q6 & Total & $\begin{array}{c}\text { Average } \\
\text { Grade }\end{array}$ & $\begin{array}{c}\text { Words/ } \\
1 \mathrm{~m}\end{array}$ & $\begin{array}{c}\text { Reading } \\
\text { Time }\end{array}$ \\
\hline 1 & $\begin{array}{l}\text { Vlorë } \\
\text { - L.Sallata }\end{array}$ & 83 & $30 / 27$ & 34 & 52 & 46 & 45 & 307 & 9 & 134.4 & 1.76 \\
\hline 2 & Vlorë- M.Delo & 77 & $26 / 19$ & 38 & 45 & 34 & 30 & 267 & 7.8 & 126.4 & 1.86 \\
\hline 3 & Vlorë - Orikum & 74 & $24 / 8$ & 43 & 37 & 22 & 27 & 235 & 7.2 & 106.4 & 2.23 \\
\hline 4 & Vlorë - Total & 234 & $80 / 64$ & 115 & 134 & 102 & 102 & 809 & 8 & 122.2 & 1.95 \\
\hline
\end{tabular}

The best school is the city school "Lef Sallata":

Question 1 - 97\% of students match parts of sentences according to the meaning;

Question $2-88 \%$ of students find words for action in the text;

Question 2/1 - 39\% of students find words for action in the text;

Question $3-66 \%$ of students find true or false statement related to the content of the text;

Question $4-76 \%$ of students explain the meaning of vocabulary words;

Question $5-90 \%$ of students of the students analyze characters;

Question $6-88 \%$ of students say that they have read novels.

The problem here that switches on what they read. The answer is random and not associated with the desire and willingness to read. From 408 test points that all the students of this class have received about 307 points. Grade passing rate is $78.5 \%$ with an average grade 9 . In this class was achieved average reading speed of 2.16' in a text with 265 words. The above results should from Vlora schools show that students have good literacy skills. Schools do good work to teach reading skills by promoting a positive reading environment.

Table 6. The test scores from 18 schools in six regions of Albania.

\begin{tabular}{|l|l|c|c|c|c|c|c|c|c|c|c|}
\hline & Regions & Q1 & Q2 & Q3 & Q4 & Q5 & Q6 & Total & $\begin{array}{c}\text { Average } \\
\text { Grade }\end{array}$ & $\begin{array}{c}\text { Words/ } \\
\text { 1m }\end{array}$ & $\begin{array}{c}\text { Reading } \\
\text { Time }\end{array}$ \\
\hline 1 & Durrës & 217 & 163 & 119 & 112 & 111 & 121 & 883 & 7.5 & 112.3 & 2.22 \\
\hline 2 & Elbasan & 212 & $72 / 42$ & 111 & 127 & 121 & 94 & 782 & 7.53 & 116.4 & 2.27 \\
\hline 3 & Vlora & 234 & $80 / 64$ & 115 & 134 & 102 & 102 & 809 & 8 & 122.2 & 1.95 \\
\hline 4 & Dibra & 194 & $78 / 29$ & 112 & 125 & 102 & 86 & 742 & 6.7 & 122.2 & 2.33 \\
\hline 5 & Gjirokastra & 145 & $59 / 17$ & 81 & 38 & 51 & 49 & 476 & 5.4 & 92,2 & 3.08 \\
\hline 6 & Korça & 222 & $79 / 55$ & 121 & 134 & 111 & 89 & 806 & 7,3 & 119.2 & 1.88 \\
\hline
\end{tabular}

There is more analytical and comparative information regarding boys and girls participating in the study. The comparison was made based on 4 variables: Passing in percentage, Average Grade, Reading speed (words/1m), Reading time. 
Table 7. Summary of results of all regions (boys-girls).

\begin{tabular}{|l|l|c|c|c|c|c|c|c|c|c|c|}
\hline & Region & $\begin{array}{c}\text { N. } \\
\text { girls }\end{array}$ & $\begin{array}{c}\text { Pass- } \\
\text { ing } \\
\text { in } \%\end{array}$ & $\begin{array}{c}\text { Aver- } \\
\text { age } \\
\text { Grade }\end{array}$ & $\begin{array}{c}\text { Words } \\
/ 1 \mathbf{m}\end{array}$ & $\begin{array}{c}\text { Read- } \\
\text { ing } \\
\text { time }\end{array}$ & $\begin{array}{c}\text { N. } \\
\text { boys }\end{array}$ & $\begin{array}{c}\text { Pass- } \\
\text { ing } \\
\text { in } \%\end{array}$ & $\begin{array}{c}\text { Aver- } \\
\text { age } \\
\text { Grade }\end{array}$ & $\begin{array}{c}\text { Words } \\
/ 1 \mathbf{m}\end{array}$ & $\begin{array}{c}\text { Read- } \\
\text { ing } \\
\text { Time }\end{array}$ \\
\hline 1 & Dibra & 25 & 64 & 6.6 & 128.1 & $2^{\prime}$ & 26 & 62 & 6.4 & 120.9 & 2.2 \\
\hline 2 & Durrësi & 25 & 69 & 7.7 & 114.6 & $2^{\prime}$ & 27 & 67.7 & 7.3 & 105.7 & 2.4 \\
\hline 3 & Elbasan & 26 & 68 & 7.8 & 116.8 & $2^{\prime}$ & 28 & 61 & 7.4 & 104.7 & 2.5 \\
\hline 4 & Vlora & 29 & 68.6 & 8.2 & 126.2 & $1.9^{\prime}$ & 22 & 61.3 & 7.8 & 114.4 & 2.6 \\
\hline 5 & $\begin{array}{l}\text { Gjirokas- } \\
\text { tra }\end{array}$ & 16 & 58.5 & 6.5 & 114 & 2.2 & 19 & 42.3 & 5.2 & 88.6 & 3.2 \\
\hline 6 & Korça & 27 & 68.6 & 7.8 & 129.4 & $1.9^{\prime}$ & 24 & 51 & 5.9 & 87 & 2.2 \\
\hline
\end{tabular}

Test results of schools of Gjirokastra Region are generally lower compared to all other regions. These lower scores are in both urban and rural schools.

Table 8. The overall results of test girls / boys.

\begin{tabular}{|c|c|c|c|c|c|c|}
\hline Nr. & Gender & N. students & $\begin{array}{c}\text { Passing } \\
\text { in } \%\end{array}$ & $\begin{array}{c}\text { Average } \\
\text { Grade }\end{array}$ & $\begin{array}{c}\text { Words } \\
/ 1 \mathrm{~m}\end{array}$ & $\begin{array}{c}\text { Reading } \\
\text { time }\end{array}$ \\
\hline 1. & Girls & 148 & 66.1 & 7.4 & 121.5 & 2 \\
\hline 2. & Boys & 146 & 57.5 & 6.6 & 103.5 & 2.5 \\
\hline 3 & Total & 294 & 61.8 & 7 & 112.5 & 2.25 \\
\hline
\end{tabular}

Scores of girls in the quality of reading are higher than the boys, they have a higher passing score, the highest grade point average, greater speed and take less time to read the similar test.

Table 9. Summary of results of rural schools.

\begin{tabular}{|l|l|c|c|c|c|c|c|c|c|c|c|}
\hline & Region & $\begin{array}{c}\text { N. } \\
\text { girls }\end{array}$ & $\begin{array}{c}\text { Passing } \\
\text { in } \%\end{array}$ & $\begin{array}{c}\text { Aver- } \\
\text { age } \\
\text { Grade }\end{array}$ & $\begin{array}{c}\text { Words } \\
/ 1 \mathrm{~m}\end{array}$ & $\begin{array}{c}\text { Read- } \\
\text { ing } \\
\text { time }\end{array}$ & $\begin{array}{c}\text { N. } \\
\text { boys }\end{array}$ & $\begin{array}{c}\text { Pass- } \\
\text { ing } \\
\text { in } \%\end{array}$ & $\begin{array}{c}\text { Aver- } \\
\text { age } \\
\text { Grade }\end{array}$ & $\begin{array}{c}\text { Words } \\
/ 1 \mathrm{~m}\end{array}$ & $\begin{array}{c}\text { Reading } \\
\text { time }\end{array}$ \\
\hline 2 & $\begin{array}{l}\text { Dibra- } \\
\text { Maqellarë }\end{array}$ & 7 & 69 & 7.1 & 141.8 & 1.9 & 9 & 56 & 6.1 & 134.6 & 1.9 \\
\hline 3 & $\begin{array}{l}\text { Durrësi- } \\
\text { M.Dollaku }\end{array}$ & 9 & 51 & 6.1 & 112.2 & 1.92 & 8 & 56 & 6.8 & 101.7 & 2.57 \\
\hline 4 & $\begin{array}{l}\text { Elbasan- } \\
\text { Kuqan }\end{array}$ & 6 & 60 & 7.0 & 102.1 & 2.89 & 11 & 51 & 7.5 & 86.8 & 3.5 \\
\hline 5 & $\begin{array}{l}\text { Vlora- } \\
\text { Orikum }\end{array}$ & 10 & 62 & 78 & 117.9 & 2.19 & 5 & 45 & 7 & 91.4 & 2.6 \\
\hline $\begin{array}{l}\text { Gjiroka- } \\
\text { stër-Ne- } \\
\text { pravishtë }\end{array}$ & 0 & - & - & - & - & 1 & 25 & 4 & 85 & 3.17 \\
\hline 6 & $\begin{array}{l}\text { Korça- } \\
\text { Zvezdë }\end{array}$ & 9 & 64 & 8.7 & 113.8 & 2.2 & 8 & 36 & 5 & 39 & 2.3 \\
\hline 7 & Total & 41 & 61.2 & 7.3 & 117.56 & 2.2 & 42 & 44.8 & 6 & 89.7 & 2.6 \\
\hline
\end{tabular}


The study shows that there is $61.8 \%$ passing with an average mark 7 (our grading system is from 1 to 10 , with 10 the highest grade). The urban schools in the project do better than the rural schools which have $53 \%$ passing. This is because less work has been done to develop students reading skills in this area.

The watch list given to teachers consisted of 14 items related to certain habits of reading. These items aim to find out teachers attitudes to student's reading skills and give them suggestions to focusing on these skills while teaching.

Table 10. Summary estimates of teacher.

\begin{tabular}{|c|l|c|c|c|}
\hline \multirow{2}{*}{} & \multirow{2}{*}{ Questions of teacher watch list } & \multicolumn{3}{|c|}{ Responses of teachers in \% } \\
\cline { 3 - 5 } & & Constantly & Sometimes & Rarely \\
\hline 1 & Showing confidence as a reader & 61 & 24 & 15 \\
\hline 2 & Variety of books to read & 56 & 33 & 11 \\
\hline 3 & Participation in the discussion readings & 44 & 33 & 23 \\
\hline 4 & The ability to make predictions about reading & 48 & 35 & 17 \\
\hline 5 & Being active to ask questions & 55 & 23 & 22 \\
\hline 6 & Retelling the content & 69 & 20 & 11 \\
\hline 7 & Finding out main ideas & 58 & 25 & 27 \\
\hline 8 & Explanation of new words & 56 & 38 & 6 \\
\hline 9 & Description of characters & 49 & 32 & 19 \\
\hline 10 & Finding solutions & 68 & 21 & 11 \\
\hline 11 & Giving alternative endings & 35 & 42 & 23 \\
\hline 12 & Recitino & 35 & 36 & 29 \\
\hline 13 & Role plays & 60 & 23 & 17 \\
\hline 14 & Storytelling & 72 & 21 & 7 \\
\hline
\end{tabular}

In the above table are given in generalizing skills of students as seen by teachers questioned: about $55 \%$ of students show accurate in relation to reading, about $30 \%$ reflecting an average and acceptable in relation with reading. What is striking is the fact that the third line of about $15 \%$ of students show general weakness in their beliefs and attitudes about reading.

At the conclusion of the assessment of teachers in classrooms should be noted that the city retained a greater consistency of behavior of pupils in relation to reading. This data comes out very positive in the regions of Vlora, Durres, Elbasan.

\section{Discussion}

Search described above reflects a real situation of a required quality and potential of a quality about reading for students in Albanian school, primary school only. Search regarding with reading aims to shed light on aspects of quality of learning as well as the test questions themselves or even in all assessment instruments relate primarily to this component. When it comes to recording quality of reading this research is not based on comparative data with those of neighboring countries or the region as the research of this nature are limited and there is no experience that could enable this kind of comparison. This research will be a modest model to look at assessment of reading and its impact on learning in addition to many other instruments that do conclude accurate.

Selected instruments were simple but significant: a simple test, an assessment sheet, a 
PROBLEMS

OF EDUCATION

IN THE $21^{\text {st }}$ CENTURY

Volume 42, 2012

60

survey and a watch list. Data processed, the adjusted and comparable between regions, rural students and urban areas, are allowed to come out at some important conclusions about the Albanian school but also to improve the quality of reading and its impact on the quality of learning.

By interpreting some of these data will be passed some arguments that would allow teachers to give recommendations for institutions, textbooks, literature and for all interested in the field of reading and understanding it in favor of learning.

One of the reasons that affect student performance is the quality of their reading. Lack of the necessary reading skills prevent the learners from understanding a given text, which leads to low levels of learning. When it comes to discussing about quality learning it would be seen as an active process where the learner uses a variety of skills and techniques to work with the text. Many researchers in the field of reading suggest many ways of teaching and forming active learners, forms which want the learner to use his/her background knowledge in order to deal with the text. They also suggest different sub skills of working with the text which help develop learners' critical thinking skills. Only in this way the learner will get the most of the texts s/he is reading. It is teacher's responsibility to lead the readers to read critically and ask questions to himself during reading and communicate with the text.

The high level of literacy is the main goal of teaching. The teacher helps the reader to connect new information with what he knows in advance, in order to find answers to questions cognitive.

Teachers play an important role in the intellectual development of students during the reading process. To better understand this role and to be successful in this role, it is important that teachers understand what happens when people read. It is very important that teachers should recognize the problems and shortcomings that their students face while reading, then set up a supplementary reading programs in order to improve students' reading skills.

Evaluations of teachers about students' reading skills and strategies are based on the daily reading activities of their students. In this assessment there is a kind of overestimation of the teachers of specific skills that they themselves have not dealt with in their teaching. Sometimes teachers do not know what books students read, while in the survey the students note that they read. Some teachers note that the students are able to characterize characters, while many students are not able to do so, as is seen from the data of the test.

Students in urban schools participating in the project score higher than the students in the urban school (Zvezda, Gjirokastra Kuqan, etc.).

In a test question asked to students about the books read, the character that was loved and author that was liked. The highest scores were achieved by students in schools in the project (Vlora, Elbasan, Durres) in which a positive environment was created for reading and students were helped by teachers with what to read, how to read and the activities to be done related to reading. In schools were lower score were achieved the answers of the students show that there has not been a specially designed program to encourage reading.

Readers of this age in these schools read only something spontaneous and rely on memorized facts. It is not the result of readings recommended and scheduled by the school. This phenomenon was observed in both city and village schools. Teachers should recommend titles of books to be read. It is also important that they are professionally developed to be good readers themselves, to know how to teach reading skills and sub skills and select the necessary reading material according to the group age they teach.

\section{Conclusions}

The study shows that reading comprehension skills are good but a lot needs to be done by the teachers to make learners learn step by step how to work with the text actively .This 
involves both getting the general meaning of the text, but also what the goal of the text is, how to ask and answer questions related to the context, and how to dive their evaluation on what they read.

It is noticed that girls do better than boys, especially in rural areas where they have many problems with reading. A negative attitude to reading and not sufficient work by school has led some of them to illiteracy.

Students in general are able to explain the meaning of new words but there are also students who do not accomplish this task. They simply characterize the characters involved in the story. They make mistakes connected with word decoding.

In terms of speed reading there is a standard already set of reading in grade five, which previously did not exist and that can serve to test in future other classes at this level. It is noted as the girls read faster and with more pleasing intonation. Students prefer such tests as they look challenging. Their significance is great as they positively affect the quality of learning.

The problems faced by students and the evaluations given by teachers highlight the fact that in order to educate positive reading skills in students teachers should pay careful attention to teaching and modeling reading skills and strategies in class. Use of extensive reading helps a lot especially when teachers carefully choose books relevant to students needs and interests and organize attractive activities with the students.

\section{Acknowledgements}

We would like to acknowledge Statistical Office of Ministry of Science and Education for the help provided to us. Special thank goes to our colleague Prof. Assoc. Elida Tabaku who encouraged us to write the article.

\section{References}

Anderson, R. C., Hiebert, E. H., \& Scott, J. A., \& Wilkinson, I. A. G. (1985). Becoming a nation of readers. Washington, DC: US Department of Education, The National Institute of Education.

Beck, I., \& Juel, C. (1999). The role of decoding in learning to read. In Reading research anthology: The why? of reading instruction, consortium on reading excellence (CORE). California, USA: Arena Press, pp. 78-88.

Burns, R. (1995). The adult learner at work. Sydney: Business and Professional Publishing.

Burns, S. (1995). Rapid changes require enhancement of adult learning. HRMonthly June, pp. 16-17.

Elley, W. B. (1991). Acquiring literacy in a second language: the effect of book-based programmes. Language Learning, 41, 375-411. DOI:10.1111/j.1467-1770.

Fasheh, M. J. (1995). The reading campaign experience within Palestinian society: innovative strategies for learning and building community. Harvard Educational Review, 65, 66-92.

Garnham, A. (2001). Mental models and the interpretation of anaphor. Hove, UK: Psychology Press.

Gernsbacher, M. A. (1990). Language comprehension as structure building. Hillsdale, NJ: Erlbaum.

Gjokutaj, M. (2009). Didaktika e gjuhës shqipe. Tiranë: Shtëpia Botuese e Librit Universitar.

Grabe, W. (1991). Current developments in second language reading research. TESOL quarterly, 25, $375-406$

Heath, S. B. (1983). Ways with words. New York: Cambridge University Press.

Jolibert, J., Gloton, R. (1975). Le pouvoir de lire. Tournay - Belgium: Casterman.

Kintsch, W. A. (1998). Comprehension: A paradigm for cognition. Cambridge: Cambridge University Press.

Mason, J., \& Allen, J. B. (1986) A review of emergent literacy with implications for research and practice in reading. Review of Research in Education, 13, 3-47. 
PROBLEMS

OF EDUCATION

IN THE $21^{\text {st }}$ CENTURY

Volume 42,2012

62

Nation, K. (2005). Connections between Language and Reading in Children with Poor Reading Comprehension. In H. W. Catts and A. G. Kamhi (eds.), The Connections between Language and Reading Disabilities, (pp. 41-55). Mahwah, NJ: Lawrence Erlbaum Associates.

Tierney, R. J., \& Pearson, P. D. (1985). Learning to Learn from Texts: A Framework for Improving Classroom Practice. In H.S. Singer and R.B. Ruddell, Eds. Theoretical Models and Processes of Reading (860-78). Newark, DE: International Reading Association.

Van Kleeck, A. (1990) Emergent literacy: learning about print before learning to read. Topics in Language Disorders, 10, 25-45.

Advised by Andromaqi Haloçi, University of Tirana, Albania

Received: January 25, 2012

Accepted: March 24, 2012

\begin{tabular}{|ll|} 
Aljula Jubani & $\begin{array}{l}\text { Prof. Assoc., Professor of Linguistic, Faculty of History - Philology, Albanian } \\
\text { Language Department, University of Tirana, Tirana, Albania. } \\
\text { E-mail: aljulajubani@yahoo.com; jubanialjula@yahoo.it; } \\
\text { Website: http//www.unitir.edu.al }\end{array}$ \\
\hline Irena Ndoci Lama & $\begin{array}{l}\text { Prof. Assoc., Professor of Didactic Literature and Italian Literature, Italian } \\
\text { Department, Faculty of Foreign, University of Tirana, Albania. } \\
\text { E-mail: irenalama@yahoo.it } \\
\text { Website: http//:www.unitir.edu.al }\end{array}$ \\
\hline Mimoza Gjokutaj & $\begin{array}{l}\text { Prof. Dr., Professor of Language Teaching, Methodology, Faculty of History } \\
\text { - Philology, Albanian Language Department, University of Tirana, Tirana, } \\
\text { Albania. } \\
\text { E-mail: mgjokutaj@yahoo.com } \\
\text { Website: http//www.unitir.edu.al }\end{array}$
\end{tabular}

